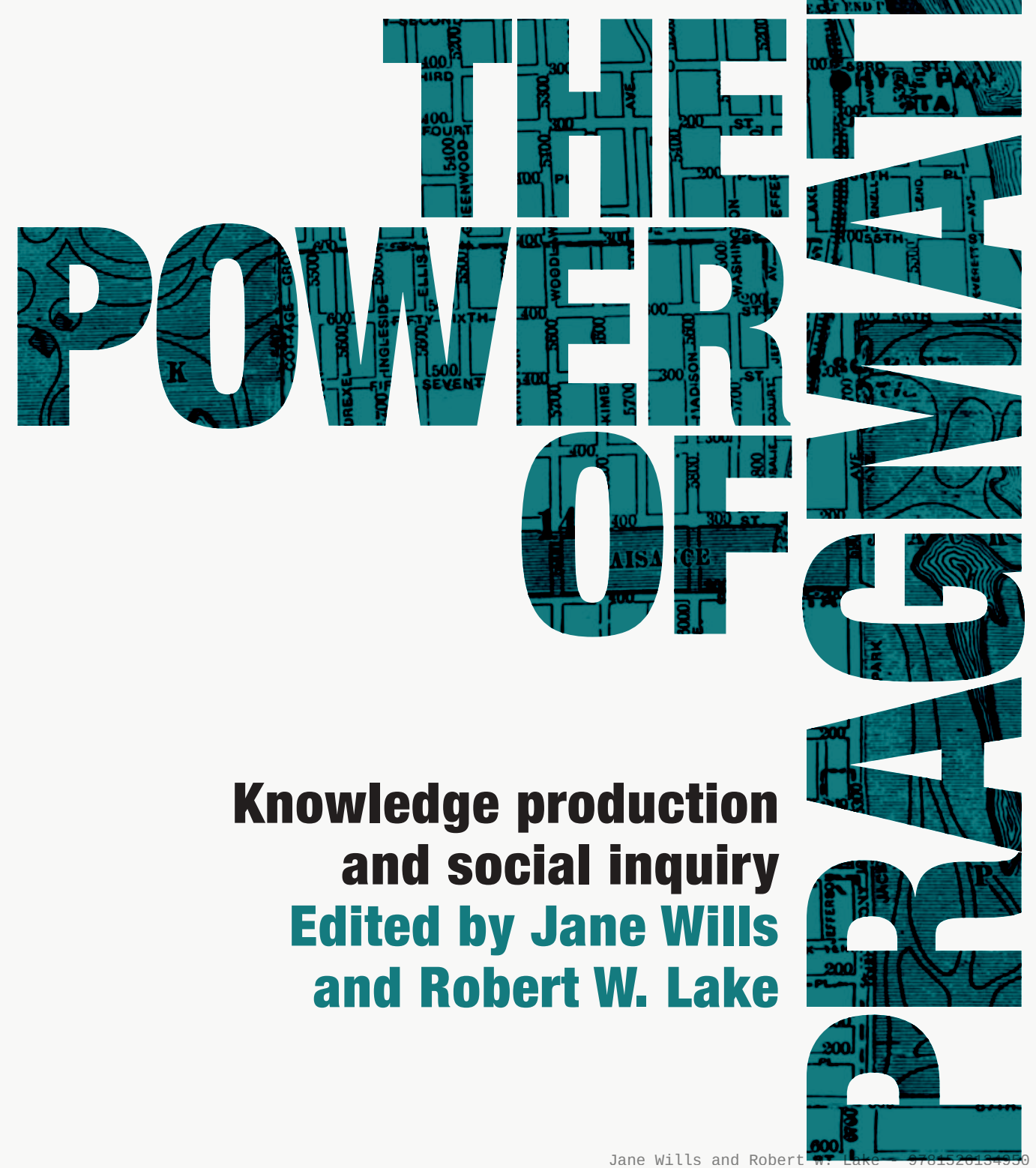




\section{The power of pragmatism}

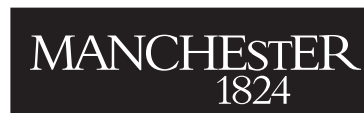

Manchester University Press 
Jane Wills and Robert W. Lake - 9781526134950 Downloaded from manchesterhive.com at 04/26/2023 11:15:43AM via free access 


\section{The power of pragmatism}

Knowledge production and social inquiry

Edited by Jane Wills and Robert W. Lake

Manchester University Press 
While copyright in the volume as a whole is vested in Manchester University Press, copyright in individual chapters belongs to their respective authors, and no chapter may be reproduced wholly or in part without the express permission in writing of both author and publisher.

Published by Manchester University Press

Altrincham Street, Manchester M1 7JA

www.manchesteruniversitypress.co.uk

British Library Cataloguing-in-Publication Data

A catalogue record for this book is available from the British Library

ISBN 9781526134943 hardback

First published 2020

The publisher has no responsibility for the persistence or accuracy of URLs for any external or third-party internet websites referred to in this book, and does not guarantee that any content on such websites is, or will remain, accurate or appropriate.

Cover image: An adaptation of Blanchard's full 1906 Chicago map, part of the David Rumsey collection (2018). Andrew Taylor via Wikimedia Commons (CC BY SA 4.0).

Typeset by Sunrise Setting Ltd, Brixham

Printed in Great Britain by

TJ International Ltd, Padstow 